Article

\title{
Experimental Study on Preparation of Ferropericlase by Oxalate Coprecipitation
}

\author{
Yanjun Xiao ${ }^{1}$, Tong Sun ${ }^{2}$ and Yong-Hong Zhao ${ }^{1, *}$ \\ 1 School of Earth and Space Science, Peking University, Beijing 100871, China; xiaoyanjun@pku.edu.cn \\ 2 School of Electronics Engineering and Computer Science, Peking University, Beijing 100871, China; \\ suntong@outlook.com \\ * Correspondence: zhaoyh@pku.edu.cn; Tel.: +86-010-62751150
}

Received: 14 January 2020; Accepted: 12 February 2020; Published: 17 February 2020

\begin{abstract}
It is always a goal of scientists to develop new techniques to identify the composition of mantle materials and understand geodynamic processes accurately. Ferropericlase $(\mathrm{Mg}, \mathrm{Fe}) \mathrm{O}$ is a prominent mineral in the lower mantel. It is a common practice in the research community to prepare ferropericlase using a solid-phase synthesis method or high-pressure experiment synthesis method. This conventional method contains a number of ambiguities a great deal of time is needed. In this paper, we have addressed the drawbacks of the conventional technique using a liquid-phase synthesis method to prepare ferropericlase. During the experiment, oxalic acid was added to a mixed solution of ferrous sulfate and magnesium chloride and mixed according to the molar ratio. The formed magnesium iron oxalate precipitate was sintered and reduced into the final sample. Furthermore, the final sample was analyzed using XRD and SEM. Compared to the solid-phase method, this coprecipitation method could produce ferropericlase with a shorter sintering time, lower sintering temperature, and a reduction in the amount of gas consumed. XRD and SEM results show that the liquid-phase method produced samples with better composition homogeneity.
\end{abstract}

Keywords: liquid-phase synthesis method; oxalate coprecipitation; ferropericlase; experimental study

\section{Introduction}

The depth of the lower mantle is $660-2890 \mathrm{~km}$, the temperature range is $1600-2450 \mathrm{~K}$, and the pressure range is 24-135 GPpa. Ferropericlase is the main mineral in the lower mantle (Manghnani, 1987 [1]; Ito and Takahashi, 1987 [2]; Irifune and Ringwood, 1987 [3]; Irifune, 1994 [4]; Murakami et al., 2005 [5]). Many researchers have studied the characterization of ferropericlase by simulating the temperature and pressure environment of the lower mantle through high-temperature and high-pressure experiments. Dubrovinsky et al. (2000) [6] simulated mantle conditions at $86 \mathrm{GPa}$ and $1000 \mathrm{~K}$ to study the stability of $\left(\mathrm{Mg}_{0.60}, \mathrm{Fe}_{0.40}\right) \mathrm{O}$, and $\left(\mathrm{Mg}_{0.50}, \mathrm{Fe}_{0.50}\right) \mathrm{O}$. Kung, $\mathrm{Li}$, and Liebermann (2004) [7] studied the rheological behavior of ferropericlase under high-temperature and high-pressure. Dubrovinsky et al. (2005) [8] studied the decomposition of magnesia under high-temperature and high-pressure. Demauchy, Mackwell, and Kohlstedt (2005) [9] studied the effect of water on the mutual diffusion of magnesium and iron in ferrites. Lin et al. (2006) [10] studied the sound velocity of ferropericlase in the earth's lower mantle. Skorikov et al. (2015) [11] studied the mechanism of the moment collapse of ferropericlase under pressure. Deng and Lee et al. (2017) [12] inferred the viscosity jump of the lower mantle from the melting curve of ferropericlase. Davies et al. (2018) [13] studied the oxygen distribution between the ferrite and the core.

High-pressure synthesis, solid-phase synthesis, and liquid-phase synthesis are the main methods to synthesize the ferropericlase solution. The majority of researchers use the solid-phase method to synthesize the $(\mathrm{Mg}, \mathrm{Fe}) \mathrm{O}$ solution, which is mainly to sinter the mixed powder of $\mathrm{MgO}$ and $\mathrm{Fe}_{2} \mathrm{O}_{3}$ at a suitable 
temperature and oxygen fugacity. At $1473 \mathrm{~K}$, the mixture of $\mathrm{MgO}$ and $\mathrm{Fe}_{2} \mathrm{O}_{3}$ powders are sintered in a $\mathrm{CO}$ and $\mathrm{CO}_{2}$ mixed atmosphere to produce ferropericlase (McCammon, Peyronneau, and Poirier, 1998 [14]). Kung et al. (2002) [15] compacted the mixture of $\mathrm{MgO}$ and $\mathrm{Fe}_{2} \mathrm{O}_{3}$ (molar ratio $=0.83: 0.085$ ) and then heated it for $24 \mathrm{~h}$ at $1473 \mathrm{~K}$ and an oxygen fugacity of $10^{-10.8}$ bar. Holzapfel et al. (2003) [16] synthesized $(\mathrm{Mg}, \mathrm{Fe}) \mathrm{O}$ by sintering a $\mathrm{Fe}_{2} \mathrm{O}_{3}$ and $\mathrm{MgO}$ mixed powder for $20 \mathrm{~h}$ at $1673 \mathrm{~K}$, with the oxygen fugacity at NNO-1.6, regrinding and then sintering twice to produce ferropericlase. Lin et al. (2005) [17] prepared polycrystalline $\left(\mathrm{Mg}_{0.83}, \mathrm{Fe}_{0.17}\right) \mathrm{O}$ samples by sintering a mixture of $\mathrm{MgO}$ and Fe powder in a controlled $\mathrm{CO}_{2}-\mathrm{CO}$ mixed atmosphere. In order to synthesize $\left(\mathrm{Mg}_{0.88}, \mathrm{Fe}_{0.12}\right) \mathrm{O}$, a mixture of $\mathrm{MgO}$ and $\mathrm{Fe}_{2} \mathrm{O}_{3}$ was sintered for $100 \mathrm{~h}$ at $1473 \mathrm{~K}$ with an oxygen fugacity of $10^{-17.4} \mathrm{~atm}$ (Keppler et al. (2007) [18]).

During the sintering process, the sample was grounded twice to make a thoroughly mixed $\mathrm{MgO}$ and $\mathrm{Fe}_{2} \mathrm{O}_{3}$ powder. Heidelbach (2009) [19] prepared $\left(\mathrm{Mg}_{0.6}, \mathrm{Fe}_{0.4}\right) \mathrm{O}$ by mixing $\mathrm{MgO}$ and $\mathrm{Fe}_{2} \mathrm{O}_{3}$ powder in the right proportion and baking at $1573 \mathrm{~K}$. The oxygen fugacity was controlled at $10^{-9}$ bar with $\mathrm{CO}-\mathrm{CO}_{2}$ mixed gas and sintered for $12 \mathrm{~h}$. Narygina (2009) [20] sintered $\mathrm{MgO}$ and $\mathrm{Fe}_{2} \mathrm{O}_{3}$ mixed powder for a whole night at $1473 \mathrm{~K}$ and an oxygen fugacity of $10^{-17.4} \mathrm{~atm}$; Otsuka and Karato (2015) [21] annealed the single crystal of ferropericlase embedded in the mixture of $\mathrm{MgO}$ and $\mathrm{Fe}_{2} \mathrm{O}_{3}$ powder at $1873 \mathrm{~K}$ and one-pascal for 200-300 h. Ohta et al. (2017) [22] synthesized polycrystalline $\left(\mathrm{Mg}_{0.81}, \mathrm{Fe}_{0.19}\right) \mathrm{O}$ at $1.2 \mathrm{GPa}$ and $1570 \mathrm{~K}$ in the barrel device of the Tokyo Institute of Technology for $19 \mathrm{~h}$ to study the thermal conductivity of periclase in the lower mantle. Fu et al. (2018) [23] sintered $\mathrm{MgO}$ and $\mathrm{Fe}_{2} \mathrm{O}_{3}$ powders at $1350 \mathrm{~K}$ using controlling a $\mathrm{H}_{2}$ and $\mathrm{CO}_{2}$ mixture to adjust oxygen fugacity for $12 \mathrm{~h}$ to obtain polycrystalline ferropericlase.

The solid-phase synthesis method directly mixes $\mathrm{MgO}$ and $\mathrm{Fe}_{2} \mathrm{O}_{3}$ powder. The initial particle diameter of $\mathrm{MgO}$ and $\mathrm{Fe}_{2} \mathrm{O}_{3}$ powder is smaller than $5 \mathrm{um}$, and the mixing time is longer to ensure the homogeneity of the sample. The starting material of the solid-phase synthesis experiment is a mixture of $\mathrm{Fe}_{2} \mathrm{O}_{3}$ and $\mathrm{MgO}$. The solid-phase reaction rate is relatively slow, and the sintering time is relatively long. The ferric iron ion in the sample is reduced to a ferrous iron ion during the sintering process. Considering the safety of the experiment, a mixture of $1 \%$ hydrogen and $99 \%$ argon is used in the experimental study. For synthesizing $\left(\mathrm{Mg}_{0.8}, \mathrm{Fe}_{0.2}\right) \mathrm{O}$, it takes a long time to synthesize the sample by the solid-phase method, which requires a reduced amount of gases.

The liquid-phase synthesis method includes hydrothermal synthesis, the sol-gel method, and the precipitation method. The precipitation method has the advantages of a simple process, low cost, and better performance of powder materials. According to different precipitation methods, it can be divided into direct precipitation, coprecipitation, and homogeneous precipitation. According to the different usage of raw materials, we can divide the precipitation method into the nitric acid precipitation method, chloride precipitation method, alcohol salt precipitation method, and oxalate precipitation method. Coprecipitation is one of the precipitation methods. It means that there are two or more cations in the solution. They exist in the solution with the same phase, adding the precipitant. After the precipitation reaction, the homogeneous precipitation of various components can be obtained. It is an important method to prepare composite oxide ultrafine powder containing two or more metal elements. Mobasherpour et al. (2007) [24] synthesized the hydroxyapatite powder from the calcium nitrate hydrated and diammonium hydrogen phosphate solution by the precipitation method and heat treatment of hydroxyapatite powders. Sinmyo et al. (2008) [25] prepared a $\left(\mathrm{Mg}_{0.899}, \mathrm{Fe}_{0.101}\right) \mathrm{SiO}_{4}$ gel starting material. The gel was entirely dehydrated by heating to $1273 \mathrm{~K}$ in a mixed atmosphere of $\mathrm{H}_{2}$ and $\mathrm{CO}_{2}$. Petcharoen and Sirivat (2012) [26] synthesized magnetite nanoparticles by chemical coprecipitation with sodium hydroxide as the precipitant. Chen and Chang (2005) [27] prepared $\mathrm{CeO}_{2}$ particles from $\mathrm{Ce}\left(\mathrm{NO}_{3}\right)_{3} \cdot 6 \mathrm{H}_{2} \mathrm{O}$ in $\mathrm{O}_{2} / \mathrm{N}_{2}$ atmosphere by the precipitation method. Zinc oxide $(\mathrm{ZnO})$ was precipitated directly in the mixed solution of zinc nitrate $\left(\mathrm{Zn}\left(\mathrm{NO}_{3}\right)_{2}\right)$ and ammonium carbonate $\left(\mathrm{NH}_{4}\right)_{2} \mathrm{CO}_{3}$ (Chen, Liu, and Lu (2009) [28]; Raoufi (2013) [29]). Wang, Gao, and Niihara (2000) [30] prepared pure yttrium aluminum garnet (YAG) phase from the reaction of aluminum and yttrium nitrate with ammonia and calcination of the resulting powder at $1173 \mathrm{~K}$. Jal et al. (2004) [31] prepared nano silica by the precipitation method. Parida et al. (2009) [32] successfully synthesized nanoporous $\gamma$-Al powder by a controlled precipitation method, using aluminum nitrate as a precursor with different 
precipitants. Supothina et al. (2007) [33] prepared tungsten oxide $\left(\mathrm{WO}_{3}\right)$ nanoparticles with an average particle size of $30 \mathrm{~nm}$ by controlling the precipitation of ammonium tungstate. Using copper nitrate $\left(\mathrm{Cu}\left(\mathrm{NO}_{3}\right)_{2}\right)$ and copper chloride $\left(\mathrm{CuCl}_{2}\right)$ as precursors, Phiwdang et al. (2013) [34] prepared $\mathrm{CuO}$ nanoparticles by the precipitation method and compared the reaction before and after preparation. Ataie and Heshmati-Manesh (2001) [35] synthesized $\mathrm{SrFe}_{12} \mathrm{O}_{19}$ hexaferrite strontium ultrafine particles with a particle size in the range of $0.1-0.2 \mu \mathrm{m}$ by a modified coprecipitation method, with the mixture of iron and strontium nitrate as raw materials. Valenzuela et al. (2009) [36] synthesized superparamagnetic magnetite nanoparticles with an average diameter of $10 \mathrm{~nm}$ by coprecipitating $\mathrm{Fe}^{2+} / \mathrm{Fe}^{3+}$ in an aqueous solution (molar ratio 1:2) and adding alkali at a mechanical stirring speed of $10,000 \mathrm{rpm} . \mathrm{BiFeO}_{3}(\mathrm{BFO})$ nanoparticles were synthesized using the coprecipitation method at $353 \mathrm{~K}$ (Shami, Awan, and Anis-ur-Rehman (2011) [37]). Nejati-Moghadam et al. (2015) [38] prepared $\mathrm{SnO}_{2}$ nanoparticles with ammonia as a precipitant and bis (acetylacetone) ethylenediamine as a capping agent by a rapid and simple coprecipitation method.

Spiridigliozzi et al. (2016) [39] synthesized nanocrystalline $20 \mathrm{~mol} \%$ samaria-doped ceria powders $\left(\mathrm{Ce}_{0.8} \mathrm{Sm}_{0.2} \mathrm{O}_{1.9}\right)$ by coprecipitation techniques with four precipitating agents in an aqueous solution: ammonia, ammonium carbonate, tetramethyl ammonium hydroxide, and urea. They found that the precipitant affected the morphology and sintering behavior of the powder. Ammonium carbonate and urea are the best precipitants to obtain the final dense products. Wu et al. (2018) [40] synthesized $\mathrm{Sr}_{1-x} \mathrm{Sm}_{x} \mathrm{Fe}_{12-x} \mathrm{Cu}_{x} \mathrm{O}_{19}$ materials by a chemical coprecipitation technique, and they found that the grain size increased with the increase of Sm-Cu content. Rezaee, Chenari, and Ghodsi (2016) [41] prepared tungsten oxide nanoparticles by the precipitation method in a different calcinations temperature $(773 \mathrm{~K}$ and $873 \mathrm{~K}$ ), and they found that the nanoparticles calcined at $773 \mathrm{~K}$ exhibited a higher photocatalytic activity for methylene blue (MB) discoloration.

The phase diagram of ferropericlase is related to the Mg:Fe ratio, oxygen fugacity, and temperature (Figure 1a,b). According to the ferropericlase phase diagrams of different temperatures, oxygen fugacity, and $\mathrm{Mg}$ :Fe ratio, the sintering time of the solid-phase sintering method is longer, the sintering temperature is relatively high, and a large amount of reducing gas and energy is consumed in the experiment. Most people who study ferropericlase will synthesize the material with a solid-phase method that spends too much time and gas. From the previous studies, it is clearly identified that a conventional method takes $12-300 \mathrm{~h}$ to prepare ferropericlase and the synthesis temperature range is from $1350 \mathrm{~K}$ to $1873 \mathrm{~K}$. The liquid-phase method would be a good way to reduce the synthesizing time. The liquid-phase method to synthesize ferropericlase is never used. Therefore, we propose a liquid-phase method to synthesize ferropericlase. In this paper, oxalic acid, magnesium chloride, ferrous sulfate, and sodium carbonate are used as raw materials, potassium hydroxide as a $\mathrm{pH}$ regulator, and the coprecipitation method is used to prepare magnesium iron oxalate precipitation. Magnesium iron oxalate precipitate is sintered at a suitable temperature with oxygen fugacity to produce ferropericlase $\left(\mathrm{Mg}_{0.8} \mathrm{Fe}_{0.2} \mathrm{O}\right)$.

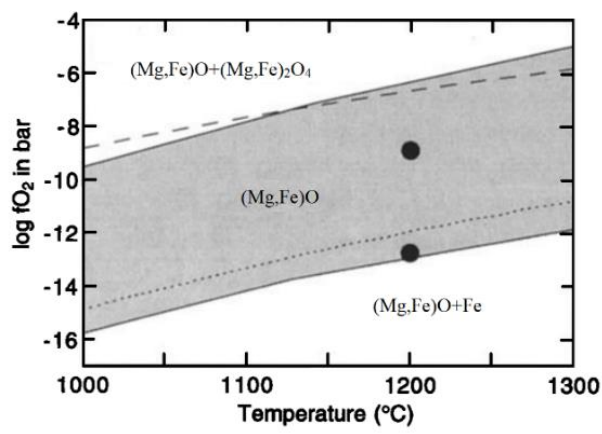

(a)

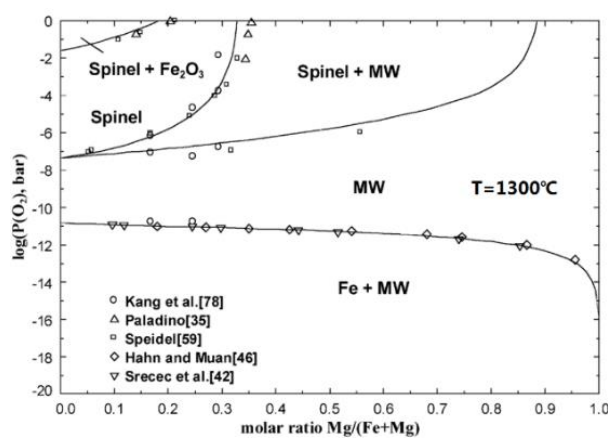

(b)

Figure 1. (a) Phase diagram of ferropericlase $\left(\mathrm{Mg}_{0.8}, \mathrm{Fe}_{0.2}\right) \mathrm{O}$ with different temperatures and oxygen fugacity (McCammon (1998)); (b) phase diagram of ferrite with different temperatures, oxygen fugacity, and magnesium-to-iron ratio (Jung, Decterov, and Pelton (2004) [42]). 


\section{Materials and Methods}

In the experiment, the solid solution precipitation of magnesium iron oxalate $\left(\mathrm{Mg}_{0.8} \mathrm{Fe}_{0.2} \mathrm{C}_{2} \mathrm{O}_{4}\right)$ was obtained using the oxalate coprecipitation method, and then the ferropericlase $\left(\mathrm{Mg}_{0.8} \mathrm{Fe}_{0.2} \mathrm{O}\right)$ was further obtained by heat treatment. The reaction equation is given below:

$$
0.2 \mathrm{Fe}^{2+}+0.8 \mathrm{Mg}^{2+}+\mathrm{C}_{2} \mathrm{O}_{4}^{2-}=\mathrm{Mg}_{0.8} \mathrm{Fe}_{0.2} \mathrm{C}_{2} \mathrm{O}_{4}
$$

The experimental materials were oxalic acid $\left(\mathrm{H}_{2} \mathrm{C}_{2} \mathrm{O}_{4}\right)$, ferrous sulfate $\left(\mathrm{FeSO}_{4}\right)$, magnesium chloride $\left(\mathrm{MgCl}_{2} \cdot 6 \mathrm{H}_{2} \mathrm{O}\right)$, potassium hydroxide $(\mathrm{KOH})$, and sodium carbonate $\left(\mathrm{Na}_{2} \mathrm{CO}_{3}\right)$. We weighed $3.25 \mathrm{~g}$ magnesium chloride hexahydrate and $0.61 \mathrm{~g}$ ferrous sulfate with an electronic balance (Table 1). In Table 1, the coefficient is the calculated materials' coefficient according to Equation (1): " $n$ " means the amount of substance, " $M$ " indicates the molecular weight, and " $m$ " is the mass of the material weighed by an electronic balance. Furthermore, water-soluble magnesium salts and ferrous salts can also be used here to produce magnesium iron oxalate, which can be extracted by filtration or other methods after the precipitation reaction.

Table 1. Raw material proportion of oxalate coprecipitation method.

\begin{tabular}{ccccc}
\hline Title & $\mathbf{M g C l}_{\mathbf{2}} \cdot \mathbf{6} \mathbf{H}_{\mathbf{2}} \mathbf{O}$ & $\mathbf{F e S O}$ & $\mathbf{H}_{\mathbf{2}} \mathbf{C}_{\mathbf{2}} \mathbf{O}_{\mathbf{4}}$ & $\mathbf{N a}_{\mathbf{2}} \mathbf{C O}_{\mathbf{3}}$ \\
\hline The coefficient & 0.8 & 0.2 & 1 & 1 \\
$n(\mathrm{~mol})$ & 0.016 & 0.004 & 0.022 & 0.022 \\
$M(\mathrm{~g} / \mathrm{mol})$ & 203.3 & 151.9 & 126 & 106 \\
$m(\mathrm{~g})$ & 3.2528 & 0.6076 & 2.772 & 2.332 \\
\hline
\end{tabular}

A proper amount of distilled water was added to the beaker to dissolve the magnesium chloride and ferrous sulfate powder. The mixed solution of magnesium chloride and ferrous sulfate could realize the molecular level full mixing of magnesium ion and iron ion. Using an electronic balance to measure $3 \mathrm{~g}$ oxalic acid crystal, it was then dissolved in $50 \mathrm{~mL}$ distilled water. It was heated slightly to make it wholly dissolved to obtain the oxalic acid solution. A total of $2.5 \mathrm{~g}$ of sodium carbonate was weighed with an electronic balance and it was dissolved in $10 \mathrm{~mL}$ of distilled water to prepare the sodium carbonate solution. Slowly, oxalic acid solution was added into the prepared sodium carbonate solution, which generated a large amount of carbon dioxide gas and generated a sodium oxalate solution. We used a buret to slowly titrate the prepared sodium oxalate solution into the mixed solution of magnesium chloride and ferrous sulfate. The formation of yellowish precipitate (magnesium iron oxalate) is observed in Figure 2. Then, $0.01 \mathrm{~mol}$ (about $0.56 \mathrm{~g}$ ) potassium hydroxide was weighed with an electronic balance and it was dissolved in $20 \mathrm{~mL}$ distilled water to prepare $0.5 \mathrm{~mol} / \mathrm{L}$ potassium hydroxide solution, which was used to adjust the $\mathrm{pH}$ value of the final mixed solution. When the $\mathrm{pH}>4$, part of the ferrous oxalate was converted into green ferrous hydroxide, and then into brown ferric hydroxide, which created adverse effects on filtration and pre-combustion. In order to avoid the mixed coprecipitation of oxalate and hydroxide and facilitate the filtration and washing, the $\mathrm{pH}$ value was usually controlled to approximately 4 .

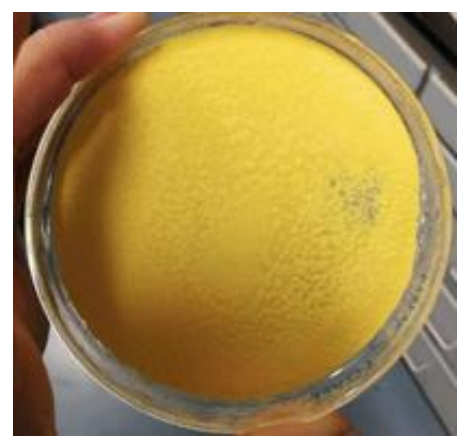

Figure 2. Magnesium iron oxalate precipitate obtained after filtration by oxalate coprecipitation method. 
The potassium hydroxide was dropped into the mixed solution to adjust the $\mathrm{pH}$ value to 3 , and then the sodium oxalate solution was added until no new precipitation occurred. We filtered out the yellowish precipitate and washed it with distilled water 3 to 4 times. The magnesium iron oxalate precipitate that was washed with water was cleaned with acetone one or two times. Then, the final cleaned magnesium iron oxalate precipitate was placed in a dry place for a period of time to volatilize the water and acetone. Tin foil or other covers were used for the container containing precipitate and holes were drilled into the tin foil paper for ventilation to ensure the evaporation of water and acetone and to avoid the mixing of pollutants. The magnesium iron oxalate precipitate was allowed to dry fully in a dryer at $373 \mathrm{~K}$ for $3 \mathrm{~h}$. The fully dried sample of magnesium iron oxalate powder was collected and put into a crucible, and then the magnesium iron oxalate powder was sintered in a vertical high-temperature furnace.

In the experimental heat treatment process (Figure 3), the temperature was first raised to $493 \mathrm{~K}$ for $1 \mathrm{~h}$, then rapidly raised to $933 \mathrm{~K}$ for $10 \mathrm{~min}$, kept for $5 \mathrm{~h}$, and then cooled to room temperature. The gas used in the whole process was argon with $1 \% \mathrm{H}_{2}$ content. A Matheson \#602 flow meter was used to measure the flow rate of the gas. The pressure reducing valve of the gas tank was 50 PSIG, the glass ball reading in the flow meter was 150 , and the corresponding flow rate was $840 \mathrm{~mL} / \mathrm{min}$. The water in the magnesium iron oxalate evaporated at $493 \mathrm{~K}$. In order to avoid oxidation of the ferrous oxide obtained from the decomposition of the magnesium iron oxalate by the evaporated water vapor, the temperature was kept at $493 \mathrm{~K}$ for $1 \mathrm{~h}$ to fully evaporate the water; at the same time, a large flow rate of gas was provided to remove the generated water vapor. Then, it was quickly heated to $933 \mathrm{~K}$. At $773-873 \mathrm{~K}$, the $\mathrm{CO}$ reducing gas obtained from the decomposition of magnesium iron oxalate and the reducing atmosphere introduced in the experiment provided a reducing environment to ensure that ferrous ions were not oxidized. Compared with the solid-phase method, there was no need to reduce the ferric ion. The requirement of reducing atmosphere in the experiment was to keep the existence of ferrous ion stable. In order to ensure the formation of $\left(\mathrm{Mg}_{0.8}, \mathrm{Fe}_{0.2}\right) \mathrm{O}$ at $933 \mathrm{~K}$, oxygen fugacity was about $10^{-17}$ atm. In the experiment, argon containing $1 \% \mathrm{H}_{2}$ was used to provide the reducing atmosphere, and finally, the ferropericlase was obtained via sintering.

$$
\mathrm{Mg}_{0.8} \mathrm{Fe}_{0.2} \mathrm{C}_{2} \mathrm{O}_{4} \stackrel{\text { heating }}{\rightarrow} \mathrm{Mg}_{0.8} \mathrm{Fe}_{0.2} \mathrm{O}+\mathrm{CO}+\mathrm{CO}_{2}
$$

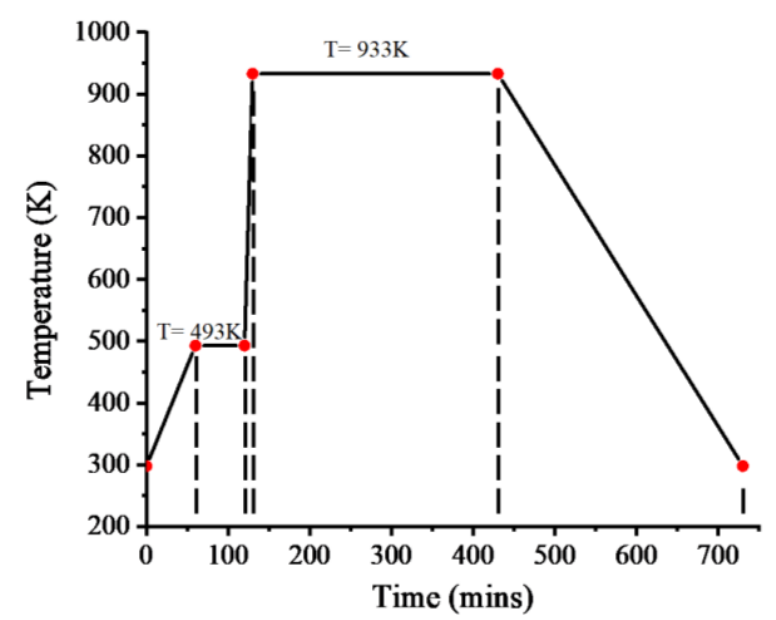

Figure 3. Heat treatment experiment condition (temperature and time).

After heat treatment, the $\mathrm{Mg}_{0.8} \mathrm{Fe}_{0.2} \mathrm{C}_{2} \mathrm{O}_{4}$ formed $\mathrm{Mg}_{0.8} \mathrm{Fe}_{0.2} \mathrm{O}$ solid solution, $\mathrm{CO}_{2}$, and $\mathrm{CO}$ gas under a reducing environment (Equation (2)). XRD (X-ray diffraction), SEM (scanning electron microscope), and EDS (energy-dispersive X-ray spectroscopy) were used to analyze the structure and composition of the final material using a solution precipitation method. 


\section{Results}

Now we will elaborate on the results step by step, which will give us a comprehensive understanding into the elaborate experimental results and help us to draw a conclusion.

\subsection{XRD Result}

XRD (X-ray diffraction) was used to analyze the structure of the synthesized material, ferropericlase. The analysis results are shown in Figure 4. The XRD spectrum was matched to the data of ferropericlase in the software database (Jade 6.0, MDI, Livermore, CA, USA). The XRD spectrum of the sample after oxalate coprecipitation and heat treatment is shown in Figure 4 in red color. The standard pattern was $\mathrm{Mg}_{1-\mathrm{x}} \mathrm{Fe}_{\mathrm{x}} \mathrm{O}$ (JCPDS(ICDD) number 351393(00-035-1393)). The ferropericlase spectrum in the database is highlighted in green in Figure 4, and the sample name is shown in blue. By comparison, it was found that there were five peak spectra in the range of $3-90^{\circ}$, and the spectral lines of ferropericlase in the database are consistent with those of XRD. The XRD results showed that the final product obtained by oxalate coprecipitation and heat treatment was ferropericlase.

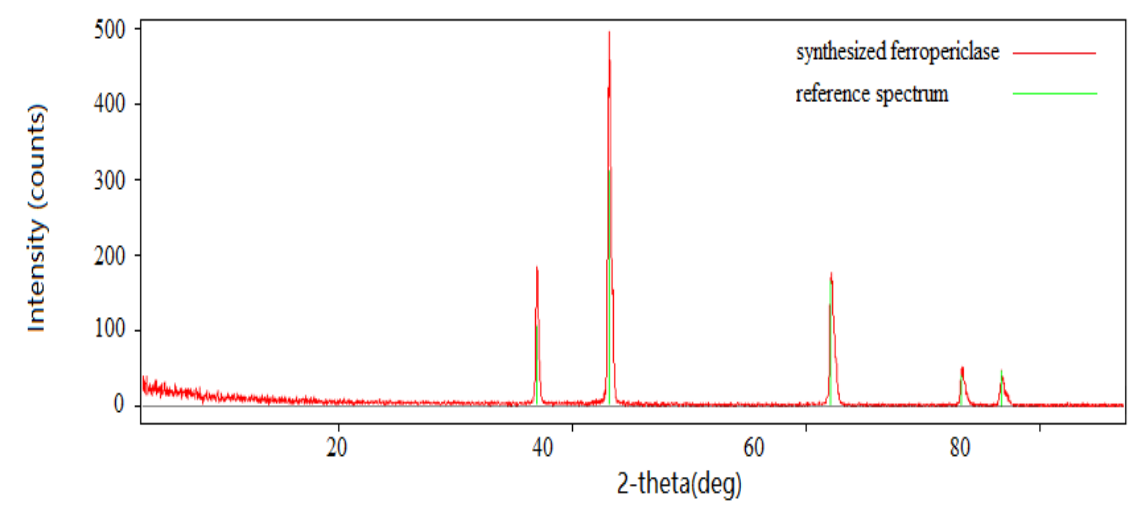

Figure 4. XRD pattern of the synthesized ferropericlase (red pattern) vs. reference spectrum (green lines).

\subsection{SEM Result}

The ferropericlase powder was obtained after heat treatment, and was a brownish-yellow powder. SEM (scanning electron microscope, phillips XL-30 SEM, F.E.I. Company, Hillsboro, OR, USA) analysis was performed for the final sample (ferropericlase) to analyze the microstructure. Figure 5 shows an SEM image for the surface of the original sample without polishing. According to the SEM image, the sample, which was obtained by oxalate coprecipitation and heat treatment, was a single-phase polycrystalline material with different grain sizes. Figure 5 shows the natural surface at different growth rates for the grain of the sintered material. It can be seen from Figure 5 that the synthesized sample was relatively dense, with small porosity and equiaxed grains. The diameters of the grains in the final sample ranged from 3 to $20 \mu \mathrm{m}$ after sintering for $5 \mathrm{~h}$. Moreover, we can also see that many ferropericlase particles were less than $10 \mu \mathrm{m}$ on the natural surface of the sample.

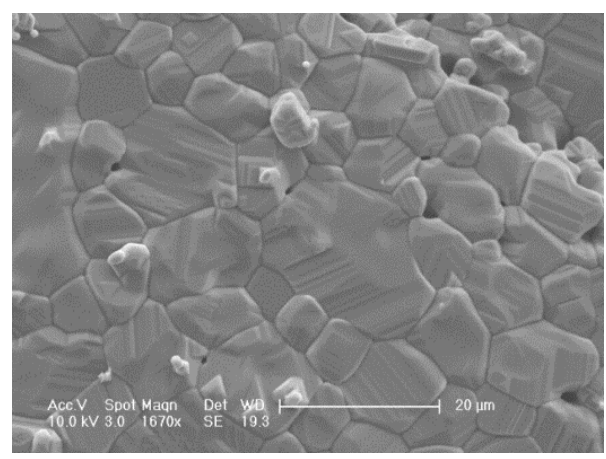

Figure 5. SEM image of ferropericlase synthesized by oxalate coprecipitation and heat treatment. 


\subsection{EDS Result}

EDS (energy dispersive spectrum) was used to measure the composition of ferropericlase, which was obtained by heat treatment after using the oxalate coprecipitation method. Table 2 shows the composition of the final sample. According to Table 2, there was $80.6 \mathrm{~mol} \% \mathrm{MgO}$ and $18.6 \mathrm{~mol} \% \mathrm{FeO}$ in the sample. The relative error of $\mathrm{MgO}$ and $\mathrm{FeO}$ content (wt. \%) in EDS quantitative analysis was less than $\pm 5 \%$.

Table 2. The composition of samples after heat treatment and oxalic acid coprecipitation.

\begin{tabular}{cccccccc}
\hline Formula & Mass $\%$ & Mol\% & Cation & Sigma & Net & K Ratio & Line \\
\hline $\mathrm{O}$ & & & & & & & $\mathrm{K}$ \\
$\mathrm{Na}$ & $\mathrm{Nd}$ & $\mathrm{Nd}$ & & & & & $\mathrm{K}$ \\
$\mathrm{MgO}$ & 69.84 & 80.60 & 19.22 & 0.35 & 592,191 & 2.4425994 & $\mathrm{~K}$ \\
$\mathrm{Al}$ & $\mathrm{Nd}$ & $\mathrm{Nd}$ & & & & & $\mathrm{K}$ \\
$\mathrm{SiO}_{2}$ & 0.13 & 0.10 & 0.02 & 0.13 & 718 & 0.0036947 & $\mathrm{~K}$ \\
$\mathrm{P}$ & $\mathrm{Nd}$ & $\mathrm{Nd}$ & & & & & $\mathrm{K}$ \\
$\mathrm{S}$ & $\mathrm{Nd}$ & $\mathrm{Nd}$ & & & & & $\mathrm{K}$ \\
$\mathrm{Cl}$ & 0.07 & 0.10 & 0.00 & 0.05 & 611 & 0.0049666 & $\mathrm{~K}$ \\
$\mathrm{~K}$ & $\mathrm{Nd}$ & $\mathrm{Nd}$ & & & & & $\mathrm{K}$ \\
$\mathrm{CaO}$ & 0.25 & 0.21 & 0.05 & 0.12 & 950 & 0.0138662 & $\mathrm{~K}$ \\
$\mathrm{TiO}$ & 0.46 & 0.27 & 0.06 & 0.18 & 846 & 0.0183841 & $\mathrm{~K}$ \\
$\mathrm{Cr}_{2} \mathrm{O}_{3}$ & 0.60 & 0.18 & 0.09 & 0.22 & 769 & 0.0278279 & $\mathrm{~K}$ \\
$\mathrm{Mn}$ & $\mathrm{Nd}$ & $\mathrm{Nd}$ & & & & & $\mathrm{K}$ \\
$\mathrm{FeO}$ & 28.65 & 18.55 & 4.42 & 0.71 & 18,907 & 1.4436706 & $\mathrm{~K}$ \\
$\mathrm{Ni}$ & $\mathrm{Nd}$ & $\mathrm{Nd}$ & & & & & $\mathrm{K}$ \\
$\mathrm{Total}$ & 100.00 & 100.00 & 23.87 & & & & \\
\hline \multicolumn{7}{c}{ “Nd"symbol means }
\end{tabular}

"Nd" symbol means not detected by EDS.

\section{Discussion and Conclusions}

Presently, the liquid-phase method is widely used in laboratories and factories to prepare ultrafine powder. For the preparation of ferropericlase, the solid-phase method is used in most experiments. Because the sintering time is long for the solid-phase synthesis method of preparing ferropericlase, large amounts of gases are needed to reduce $\mathrm{Fe}^{3+}$ to $\mathrm{Fe}^{2+}$ during the experimental process. Furthermore, the solid-phase method needs a higher temperature and longer time, which is a waste of energy. The liquid-phase method can achieve the molecular level mixing of magnesium ions and iron ions. At the same time, the ferrous ion salt solution is used without reducing from ferric iron ions. Compared with the solid-phase method, the liquid-phase method has the advantages of shorter preparation time, less atmosphere consumption, and better uniformity of composition.

In this paper, we proposed a liquid-phase oxalate coprecipitation method to synthesize ferropericlase $\left(\mathrm{Mg}_{0.8} \mathrm{Fe}_{0.2} \mathrm{O}\right)$. The ferropericlase obtained by the new method has been studied using characterization techniques, such as XRD (X-ray diffraction), EDS (energy dispersive spectrum), and SEM (scanning electron microscopy). The XRD and SEM results show that the liquid-phase method produces ferropericlase $\left(\mathrm{Mg}_{0.8} \mathrm{Fe}_{0.2} \mathrm{O}\right)$ as a single-phase polycrystalline material. The grain size is not uniform, which ranges from 3 to $20 \mu \mathrm{m}$. The morphology and grain size of ferropericlase $\left(\mathrm{Mg}_{0.8} \mathrm{Fe}_{0.2} \mathrm{O}\right)$ may be related to the precipitant and sintering time. The new method alleviates the roadblock's characteristic to a conventional "shake and bake" synthetic approach, and it is also advantageous because the decomposition of the oxalate intermediate provides a reducing atmosphere $(\mathrm{CO})$ for the reduction of iron ions, stabilizing the ferropericlase phase. We also want to identify whether the CO gas is produced with the decomposition of magnesium iron oxalate in the heat treatment process, which will reduce the ferrous iron to metallic iron in our sampling process. The $1 \% \mathrm{H}_{2}$ is replaced with Ar gas with a purity of $99.99 \%$ during heat treatment. The SEM result also shows that there is no metallic iron formed, which means that the sample is still a solid solution of ferropericlase. 
In this work, a dense and single-phase polycrystalline ferropericlase was successfully synthesized from precipitates obtained using the oxalate coprecipitation method. According to the oxalate coprecipitation method mentioned in this paper, polycrystalline ferropericlase with different iron-to-magnesium ratios can theoretically be synthesized. In the future, we will hope to study the effects of temperature, different precipitants, different iron-to-magnesium ratios, and sintering time on the growth rate and morphology of particles.

Author Contributions: Conceptualization, Y.-H.Z. and Y.X.; methodology, T.S.; validation, Y.X.; formal analysis, Y.X.; resources, Y.-H.Z.; writing—original draft preparation, Y.X.; writing-review and editing, Y.-H.Z.; All authors have read and agreed to the published version of the manuscript.

Funding: This research is supported by National Key R\&D Program of China (Grant Number 2018YFC1504203, SQ2017YFSF040025).

Acknowledgments: We thank Zhenting Jiang for helping us in data analysis (XRD and SEM). Thanks Muhammad Irfan Ehsan for helping us to revise and polish the paper.

Conflicts of Interest: The authors declare no conflict of interest.

\section{References}

1. Manghnani, M.H. High Pressure Research in Mineral Physics; American Geophysical Union: Washington, DC, USA, 1987.

2. Ito, E.; Takahashi, E. Ultrahigh-pressure phase transformations and the constitution of the deep mantle. In High-Pressure Research in Mineral Physics; American Geophysical Union: Washington, DC, USA, 1987; pp. 221-229.

3. Irifune, T.; Ringwood, A.E. Phase transformations in primitive MORB and pyrolite compositions to $25 \mathrm{GPa}$ and some geophysical implications. High Press. Res. Miner. Phys. 1987, 39, 235-246.

4. Irifune, T. Absence of an aluminous phase in the upper part of the Earth's lower mantle. Nature 1994, 370, 131. [CrossRef]

5. Murakami, M.; Hirose, K.; Sata, N.; Ohishi, Y. Post-perovskite phase transition and mineral chemistry in the pyrolitic lowermost mantle. Geophys. Res. Lett. 2005, 32, L03304. [CrossRef]

6. Dubrovinsky, L.S.; Dubrovinskaia, N.A.; Saxena, S.K.; Annersten, H.; Hålenius, E.; Harryson, H.; Tutti, F.; Rekhi, S.; Le Bihan, T. Stability of ferropericlase in the lower mantle. Science 2000, 289, 430-432. [CrossRef] [PubMed]

7. Kung, J.; Li, B.; Liebermann, R.C. Elasticity of ferropericlase at high pressure and temperature: Implications in earth's interior. In AGU Fall Meeting Abstracts; American Geophysical Union: Washington, DC, USA, 2004.

8. Dubrovinsky, L.; Dubrovinskaia, N.; Kantor, I.; McCammon, C.; Crichton, W.; Urusov, V. Decomposition of ferropericlase $\left(\mathrm{Mg}_{0.80} \mathrm{Fe}_{0.20}\right) \mathrm{O}$ at high pressures and temperatures. J. Alloy. Compd. 2005, 390, 41-45. [CrossRef]

9. Demouchy, S.; Mackwell, S.J.; Kohlstedt, D.L. Effect of hydrogen on Mg-Fe interdiffusion in ferro-periclase. In AGU Fall Meeting Abstracts; American Geophysical Union: Washington, DC, USA, 2005.

10. Lin, J.F.; Jacobsen, S.D.; Sturhahn, W.; Jackson, J.M.; Zhao, J.; Yoo, C.S. Sound velocities of ferropericlase in the Earth's lower mantle. Geophys. Res. Lett. 2006, 33, L22304. [CrossRef]

11. Skorikov, N.A.; Shorikov, A.O.; Skornyakov, S.L.; Korotin, M.A.; Anisimov, V.I. Mechanism of magnetic moment collapse under pressure in ferropericlase. J. Phys. Condens. Matter 2015, 27, 275501. [CrossRef]

12. Deng, J.; Lee, K.K.M. Viscosity jump in the lower mantle inferred from melting curves of ferropericlase. Nat. Commun. 2017, 8, 1997. [CrossRef]

13. Davies, C.J.; Pozzo, M.; Gubbins, D.; Alfè, D. Partitioning of oxygen between ferropericlase and earth's liquid core. Geophys. Res. Lett. 2018, 45, 6042-6050. [CrossRef]

14. McCammon, C.; Peyronneau, J.; Poirier, J.P. Low ferric iron content of ( $\mathrm{Mg}, \mathrm{Fe}) \mathrm{O}$ at high pressures and temperatures. Geophys. Res. Lett. 1998, 25, 1589-1592. [CrossRef]

15. Kung, J.; Li, B.; Weidner, D.J.; Zhang, J.; Liebermann, R.C. Elasticity of $\left(\mathrm{Mg}_{0.83}, \mathrm{Fe}_{0.17}\right) \mathrm{O}$ ferropericlase at high pressure: Ultrasonic measurements in conjunction with X-radiation techniques. Earth Planet. Sci. Lett. 2002, 203, 557-566. [CrossRef] 
16. Holzapfel, C.; Rubie, D.C.; Mackwell, S.; Frost, D.J. Effect of pressure on Fe-Mg interdiffusion in $\left(\mathrm{Fe}_{\mathrm{x}} \mathrm{Mg}_{1-\mathrm{x}}\right) \mathrm{O}$, ferropericlase. Phys. Earth Planet. Inter. 2003, 139, 21-34. [CrossRef]

17. Lin, J.F.; Struzhkin, V.V.; Jacobsen, S.D.; Hu, M.Y.; Chow, P.; Kung, J.; Liu, H.; Mao, H.; Hemley, R.J. Spin transition of iron in magnesiowüstite in the Earth's lower mantle. Nature 2005, 436, 377. [CrossRef] [PubMed]

18. Keppler, H.; Kantor, I.; Dubrovinsky, L.S. Optical absorption spectra of ferropericlase to 84 GPa. Am. Mineral. 2007, 92, 433-436. [CrossRef]

19. Heidelbach, F.; Terry, M.P.; Bystricky, M.; Holzapfel, C.; McCammon, C. A simultaneous deformation and diffusion experiment: Quantifying the role of deformation in enhancing metamorphic reactions. Earth Planet. Sci. Lett. 2009, 278, 386-394. [CrossRef]

20. Narygina, O.; Mattesini, M.; Kantor, I.; Pascarelli, S.; Wu, X.; Aquilanti, G.; McCammon, C.; Dubrovinsky, L. High-pressure experimental and computational XANES studies of $(\mathrm{Mg}, \mathrm{Fe})(\mathrm{Si}, \mathrm{Al}) \mathrm{O}_{3}$ perovskite and $(\mathrm{Mg}, \mathrm{Fe}) \mathrm{O}$ ferropericlase as in the Earth's lower mantle. Phys. Rev. B 2009, 79, 174115. [CrossRef]

21. Otsuka, K.; Karato, $\mathrm{S}$. The influence of ferric iron and hydrogen on Fe-Mg interdiffusion in ferropericlase $((\mathrm{Mg}, \mathrm{Fe}) \mathrm{O})$ in the lower mantle. Phys. Chem. Miner. 2015, 42, 261-273. [CrossRef]

22. Ohta, K.; Yagi, T.; Hirose, K.; Ohishi, Y. Thermal conductivity of ferropericlase in the Earth's lower mantle. Earth Planet. Sci. Lett. 2017, 465, 29-37. [CrossRef]

23. Fu, S.; Yang, J.; Zhang, Y.; Liu, J.; Greenberg, E.; Prakapenka, V.B.; Okuchi, T.; Lin, J.-F. Melting behavior of the lower-mantle ferropericlase across the spin crossover: Implication for the ultra-low velocity zones at the lowermost mantle. Earth Planet. Sci. Lett. 2018, 503, 1-9. [CrossRef]

24. Mobasherpour, I.; Heshajin, M.S.; Kazemzadeh, A.; Zakeri, M. Synthesis of nanocrystalline hydroxyapatite by using precipitation method. J. Alloy. Compd. 2007, 430, 330-333. [CrossRef]

25. Sinmyo, R.; Hirose, K.; Nishio-Hamane, D.; Seto, Y.; Fujino, K.; Sata, N.; Ohishi, Y. Partitioning of iron between perovskite/postperovskite and ferropericlase in the lower mantle. J. Geophys. Res. Solid Earth 2008, 113, B11204. [CrossRef]

26. Petcharoen, K.; Sirivat, A. Synthesis and characterization of magnetite nanoparticles via the chemical co-precipitation method. Mater. Sci. Eng. B 2012, 177, 421-427. [CrossRef]

27. Chen, H.I.; Chang, H.Y. Synthesis of nanocrystalline cerium oxide particles by the precipitation method. Ceram. Int. 2005, 31, 795-802. [CrossRef]

28. Chen, C.C.; Liu, P.; Lu, C.H. Synthesis and characterization of nano-sized ZnO powders by direct precipitation method. Chem. Eng. J. 2008, 144, 509-513. [CrossRef]

29. Raoufi, D. Synthesis and microstructural properties of $\mathrm{ZnO}$ nanoparticles prepared by precipitation method. Renew. Energy 2013, 50, 932-937. [CrossRef]

30. Wang, H.; Gao, L.; Niihara, K. Synthesis of nanoscaled yttrium aluminum garnet powder by the co-precipitation method. Mater. Sci. Eng. A 2000, 288, 1-4. [CrossRef]

31. Jal, P.K.; Sudarshan, M.; Saha, A.; Patel, S.; Mishra, B.K. Synthesis and characterization of nanosilica prepared by precipitation method. Colloids Surf. A Physicochem. Eng. Asp. 2004, 240, 173-178. [CrossRef]

32. Parida, K.M.; Pradhan, A.C.; Das, J.; Sahu, N. Synthesis and characterization of nano-sized porous gamma-alumina by control precipitation method. Mater. Chem. Phys. 2009, 113, 244-248. [CrossRef]

33. Supothina, S.; Seeharaj, P.; Yoriya, S.; Sriyudthsak, M. Synthesis of tungsten oxide nanoparticles by acid precipitation method. Ceram. Int. 2007, 33, 931-936. [CrossRef]

34. Phiwdang, K.; Suphankij, S.; Mekprasart, W.; Pecharapa, W. Synthesis of CuO nanoparticles by precipitation method using different precursors. Energy Procedia 2013, 34, 740-745. [CrossRef]

35. Ataie, A.; Heshmati-Manesh, S. Synthesis of ultra-fine particles of strontium hexaferrite by a modified co-precipitation method. J. Eur. Ceram. Soc. 2001, 21, 1951-1955. [CrossRef]

36. Valenzuela, R.; Fuentes, M.C.; Parra, C.; Baeza, J.; Duran, N.; Sharma, S.K.; Knobel, M.; Freer, J. Influence of stirring velocity on the synthesis of magnetite nanoparticles $\left(\mathrm{Fe}_{3} \mathrm{O}_{4}\right)$ by the co-precipitation method. J. Alloy. Compd. 2009, 488, 227-231. [CrossRef]

37. Shami, M.Y.; Awan, M.S.; Anis-ur-Rehman, M. Phase pure synthesis of $\mathrm{BiFeO}_{3}$ nanopowders using diverse precursor via co-precipitation method. J. Alloy. Compd. 2011, 509, 10139-10144. [CrossRef]

38. Nejati-Moghadam, L.; Esmaeili Bafghi-Karimabad, A.; Salavati-Niasari, M.; Safardoust, H. Synthesis and characterization of $\mathrm{SnO}_{2}$ nanostructures prepared by a facile precipitation method. J. Nanostruct. 2015, 5, 47-53. 
39. Spiridigliozzi, L.; Dell'Agli, G.; Biesuz, M.; Sglavo, V.M.; Pansini, M. Effect of the precipitating agent on the synthesis and sintering behavior of $20 \mathrm{~mol} \mathrm{Sm-doped} \mathrm{ceria.} \mathrm{Adv.} \mathrm{Mater.} \mathrm{Sci.} \mathrm{Eng.} \mathrm{2016,} \mathrm{2016,} \mathrm{1-8.} \mathrm{[CrossRef]}$

40. Wu, Z.; Zhang, R.; Yu, Z.; Shan, L.; Dong, L.; Zhang, X. The magnetic properties of permanent strontium ferrite doped with rare-earth by chemical co-precipitation method. Ferroelectrics 2018, 529, 120-127. [CrossRef]

41. Rezaee, O.; Chenari, H.M.; Ghodsi, F.E. Precipitation synthesis of tungsten oxide nanoparticles: X-ray line broadening analysis and photocatalytic efficiency study. J. Sol-Gel Sci. Technol. 2016, 80, 109-118. [CrossRef]

42. Jung, I.H.; Decterov, S.A.; Pelton, A.D. Critical thermodynamic evaluation and optimization of the Fe-Mg-O system. J. Phys. Chem. Solids 2004, 65, 1683-1695. [CrossRef]

(C) 2020 by the authors. Licensee MDPI, Basel, Switzerland. This article is an open access article distributed under the terms and conditions of the Creative Commons Attribution (CC BY) license (http://creativecommons.org/licenses/by/4.0/). 